\title{
Estimating R\&D Returns In Health Care Industry
}

\author{
Waldemar Karpa ${ }^{1}$, Jakub Nowakowski ${ }^{2}$
}

Submitted: 02.07.17. Final acceptance: 10.04.18

\section{Abstract}

Purpose: This paper provides an empirical evaluation of R\&D returns for a series of global companies who lead in innovation within the health care industry.

Methodology: The estimation procedure bases on two specifications: the parametric production function setting, and finite distributed lag model (FDL).

Findings: Using the most recent data on R\&D investment by health care equipment and services along pharmaceuticals and biotechnology companies, we confirm the positive albeit mitigated impact of R\&D efforts on performance indicators (levels of sales). Moreover, we comment on the current phenomena observed in health care industry and offer a policy view for ongoing and future challenges in the sector.

Added value: Since there is a dearth of recent empirical evidence on R\&D returns in the broad health industry, this paper offers the evaluation of economic incentives for companies to invest in $\mathrm{R} \& \mathrm{D}$. These incentives embrace the induced increase in sales and profits levels. The authors participate in a public debate concerning the optimal levels of $R \& D$ rewards required to sustain the innovation within the sector.

Keywords: R\&D, innovation, industrial policy, health economics, health policy

JEL: D22, 03, I11

\footnotetext{
1 Kozminski University

Correspondence address: Kozminski University, 59 Jagiellonska St., 03-301 Warsaw, Poland, e-mail: wkarpa@kozminski.edu.pl

2 PhD Candidate Kozminski University, e-mail: nowakow.jakub@gmail.com
} 


\section{Introduction}

According to the most recent Thomson Reuters State of Innovation report, companies that operate globally in health care sector generated more than $30 \%$ of innovations worldwide in 2015, of which medical equipment and pharmaceutical firms contributed 18\% while biotechnology companies the remaining part (Thomson Reuters, 2016). The benefits of health-related innovations are unquestionable. Suffice to consider the biopharmaceutical industry; between 1982 and 2001, new medicines have participated in a $40 \%$ increase in the length of life, while the entire health industry has significantly improved our quality of life (Lichtenberg, 2003). Health industry continues to provide high societal value through innovations and large investments of money and time to improve the global public health. The health sector does that by employing strategies based on blending resources: financing, scientific knowledge, and commercial abilities. However, the health industry faces new challenges that may stunt this innovation pipeline. These challenges mainly include stagnating private and public investments, complex and fragmented regulatory processes, and growing approval cycles (Deloitte, 2014). While health industry spends the highest proportion of revenue on R\&D among other sectors comparable in technology-intensity, it displays the highest rate of uncertainty related to the development process. For instance, in the case of pharma companies, only less than $70 \%$ of new molecules will eventually reach the market (Paul et al., 2010). At the same time, the health industry faces troubling adversities. First, for five years now, there has been a pronounced decline in the amount of venture capital engaged in the early development stage. In the case of the medical sector, the financial resources are of extreme importance in securing the process of identification of a molecule for a future drug or work on a medical device prototype (Fleming, 2015). Second, the pharmaceutical sector has witnessed a decline in economic returns from new drugs (Berndt et al., 2015). The conjunction of these phenomena overshadows the future performances of the health sector and questions the expected health benefits from technological progress. Therefore, investigating returns from medical R\&D seems crucial in terms of both economic impact and public health policies.

\section{The Goal of the Study}

We wish to assess the returns from R\&D investments realized by leading global companies in the health industry. To achieve this goal, we derive a model based on the production function setting and long-run multiplier estimator of R\&D returns. Consequently, using the most recent data on R\&D intensity, we analyze the effects of R\&D efforts on economic outcomes for a panel of companies that operate in two subsectors: health care equipment and services; pharmaceuticals and biotechnology. 


\section{Organization of the Study}

Section 2 elaborates the rationale for R\&D decisions and characterizes the methods of R\&D returns evaluation. Section 3 develops our empirical strategy, details the modeling procedure, and describes data. The following section examines the results, while the last one discusses the results from the policy perspective.

\section{The return on investment nexus}

Return on investment in $\mathrm{R} \& \mathrm{D}$ and its impact on innovation processes is greatly important for managers, economists, and policymakers (Mairesse and Mohnen, 2005; Yunkui and Wang, 2001). This is because, on the one hand, the R\&D processes and innovation pipelines are intensive in terms of resources and, on the other hand, the need for rational action focuses economic agents on avoiding too much risk (Wang and Chung-Yu, 2012; Lai and Gwo-Guang, 2007) and ensuring positive return on investment.

If we look at R\&D from the perspective of a given company, there are expectations that investment into research and development yields competitive advantages (Lichtenberg and Siegel, 1991; 1992; Artz et al., 2010; Bowonder et al., 2010; García-Manjón and Romero-Merino, 2012) through novel products or services, or creates added value for current products by making them more profitable and competitive on the market, thus positively affecting the overall efficiency of the company (Tubbs, 2007). At the same time, we need to remember that allocating resources in research and development does not guarantee positive returns in terms of increased profit levels or stock market values.

Spending on research and development seems to have a dual nature, as it is both similar and different to the ordinary physical capital investment. The elementary similarity lies in the expectation that present investment in $\mathrm{R} \& \mathrm{D}$ (the expenditure) will gain positive returns in the future (Griliches, 1981; Li, 2011; Hitt et al., 1991). However, in the case of R\&D spending, as with any other investment, we cannot secure positive returns (Griliches, 1998). Indeed, sometimes it is difficult to break even, not to mention financial profit. Sometimes, the only profits from R\&D expenditures are intangible and nonmeasurable (Ballester Garcia-Ayuso and Livnat, 2003; Barth and McNichols, 2001; Canibano, Garcia-Ayuso, and Sanchez, 2000). The differences between physical capital investment and R\&D investment are substantial and have been clearly identified in the literature (Arrow, 1962). With R\&D investment, companies seek creating intangible assets, so-called know-how, or just the knowledge how to do something better and faster (Barth et al., 2001; Sougiannis 1994). Compared to physical capital investments, there is a lot 
more uncertainty associated with the final outcomes of these assets (Nissim and Thomas, 2000).

The differences in tangible versus intangible capital investment create a duality in the approaches to R\&D spending. From the macroeconomic perspective, R\&D investment should secure long-term growth, because the returns from knowledge-intensive capital should exceed the returns from physical capital and labor (Bilbao-Osorio and Rodriguez-Pose, 2004; Bogliancino and Vivarelli, 2010). In turn, the microeconomic approach privileges focusing on a series of financial indicators, such as profit margin, operating margin, capitalization growth ratio, or the stock return for shareholders (Hsieh, Chandra and Gobeli 2003; Morbey and Reithner, 1990).

The most common functional approach to measuring R\&D investments functions in two methodologies. First, the Market Values approach (ex-ante evaluation) links the future stock market value of the company to current R\&D investment decisions, focusing on the expected future returns instead of current profit levels. Griliches (1981), Li (2011), Hitt et al. (1991), Chambers et al. (2002), described this approach, which scholars later empirically verified with the data from a number of countries such as the USA (Cockburn and Griliches, 1987; Hall, 1993), United Kingdom (Blundell et al., 1999; Toivanen et al., 2002; Al-Horani et al., 2003), Australia (Bosworth and Rogers, 2001), Europe (Hall and Oriani, 2006), and Japan (Nagaoka, 2006). According to these findings, there is a correlation between stock company value and R\&D expenditures (Hall and Mairesse, 2009). The second approach bases on production function specification (ex-post evaluation).

\section{Empirical strategy}

R\&D expenditures count among the oldest metrics of innovation, along with education spending, research workforce, and similar measurements that focus on inputs (Milbergs and Vonortas, 2004). Moreover, economists, policymakers, and managers have been considerably interested in evaluating returns on R\&D investments. Because investing in $\mathrm{R} \& \mathrm{D}$ remains expensive and risky, ensuring positive returns is a quite challenging task that affects both current and future outcomes. Therefore, R\&D management requires the consideration of existing empirical evidence, intertemporal planning perspective, and industry-specific factors.

Beginning with the seminal paper of Griliches (1979), the empirical evidence of R\&D returns stems from growth accounting framework, in which the unexplained part of 
growth, namely technical change, resulted from R\&D activities once we accounted for the increase in output levels and attributed it to total factor productivity (TFP). Scholars have frequently modified this theoretical framework, adjusting for endogenous productivity (Doraszelski and Jaumandreu, 2013), technology, market spillovers (Bloom, Schankerman and van Reenen, 2013), and firms' exporting activities (Aw, Roberts and $\mathrm{Xu}, 2011$ ). The existing literature provides a wide range of empirical studies at different levels of aggregation (micro/mezzo/macro) in a variety of industrial sectors. The production function approach, however, still remains a valid and convenient tool for investigating the R\&D nexus.

\section{The Model}

We proceed with two functional specifications. The first builds on the modeling of Griliches (1986), Mairesse and Sassenou (1991) and Harhoff (1996), which bases on the production function, while the second employs the finite distributed lag model (FDL). The rationale for this choice is twofold. On the one hand, we test the relevance of production function approach to evaluate recent R\&D returns in the health care industry (pharma and equipment) and compare our results with previous empirical studies. On the other hand, we check whether R\&D expenditures in the health care sector can enjoy multiplier effects.

\section{a) Production function specification}

The production function is a usual Cobb-Douglas function with three inputs: labor (L), physical capital (C), and knowledge capital (K) in the form of R\&D. The output corresponds to the value of annual sales (Y), $\lambda$ is the rate of technological change, while (A) is the usual scaling parameter. Below, we present a model applicable to a sample of firms (i) from 2014-2016:

$$
S_{i t}=\mathrm{A}_{i} \exp (\lambda t) C_{i t}^{\alpha} L_{i t}^{\mu} K_{i t}^{\gamma} \exp \left(\varepsilon_{i t}\right)
$$

One may estimate Equation (1) with OLS mechanics. Thus, after logarithmic transformation, Equation 2 describes the econometric model:

$$
s_{i t}=\mathrm{a}_{i}+\lambda t+\alpha c_{i t}+\beta l_{i t}+\gamma k_{i t}+\varepsilon_{i t}
$$

Subtracting labor from (2) provides us with capital/labor ratios as in Equation (3):

$$
s_{i t}-l_{i t}=\mathrm{a}_{i}+\lambda t+\alpha\left(c_{i t}-l_{i t}\right)+\gamma\left(k_{i t}-l_{i t}\right)+(\mu-1) l_{i t}+\varepsilon_{i t}
$$


in which $\mu=(\alpha+\beta+\gamma)$. Moreover, we may reject the constant returns to scale if estimated labor coefficient significantly differs from zero.

Because variables included in (3) are the logarithms of initial values, one may interpret them as elasticities. We are specifically interested in evaluating $\gamma$, because this is the elasticity of R\&D with respect to sales.

\section{b) FDL model}

In this specification, we allow R\&D investment expenditure to affect the current sales levels with a lag. In the case of the health care industry, the innovation process not only costs much but also the effects of R\&D efforts stretch in time. Moreover, current investment in R\&D decreases current profits while the effect on future benefits remains highly uncertain. Although investment in knowledge capital should increase the probability of novelties commercialization and implicitly raise the level of sales and profits associated with the future monopoly rents attributable to technology ownership, only a tiny portion of novel ideas in the health industry end up on the market. This is so because the sale of drugs and medical equipment relies on the validation of regulatory authorities, which frequently defers and diminishes the perspective of huge profits. On the other hand, the literature acknowledges that the probability of future innovation, as well as its dynamics, accompanies the accumulated R\&D stock. Accordingly, we propose the following model in Equation 4:

$$
S_{i, t}=K_{i, t}+K_{i, t-1}+K_{i, t-2}
$$

in which $S$ describes the sales level for a firm $i$ at time $t ; K_{i, t}$ - current level of R\&D expenditures; and $K_{i, t-1,} K_{i, t-1}$ - past levels of R\&D expenditures.

After logarithmic transformation, the initial econometric model based on (4) appears in the form of Equation 5:

$$
S_{i, t}=\alpha_{0}+\delta_{1} k_{i, t}+\delta_{2} k_{i, t-1}+\delta_{2} k_{i, t-2}+u_{t}
$$

Since the series of R\&D (lags) strongly correlate, the estimation of (5) without assumptions on $\delta$ distribution would yield a biased estimator due to the issues of multicollinearity. Therefore, we assume that the lag distribution is flat $-\delta_{0}=\delta_{1}=\delta_{2}=\delta$ - and transform the model (5) into the reduced form of Equation 6:

$$
S_{t}=\beta_{0}+\delta_{Z}+u_{t} \text { and }\left(Z \equiv K_{t}+K_{t-1}+K_{t-2}\right)
$$




\section{Data}

We compiled our dataset from the EU Industrial R\&D Investment Scoreboard, developed by the European Commission's Joint Research Centre (JRC), the Institute for Prospective Technological Studies (IPTS), and the Directorate General for Research and Innovation. The Scoreboard receives annual updates since 2004, with the goal of monitoring the leading R\&D companies in Europe and benchmarking them with top R\&D firms worldwide. The initial dataset embraces economic and financial information on the global top 2500 firms that "invested $€ 607.2$ billion in R\&D - representing about $90 \%$ of the total expenditure on R\&D by business worldwide" (JRC, 2015). The data come from the companies' annual reports, grouped by firms' location region and industrial sector.

We have extracted information from the industrial sectors of health care equipment and services alongside pharmaceuticals and biotechnology. We narrowed the initial sample of 467 firms from both sectors to 339 and 318 companies accordingly, with complete information on production function set-up versus FDL. The datasets cover the full three-year period of 2014-2016 along with the following series of variables:

- Net sales (S), €k: accounting value of annual sales, excluding sales taxes.

- Research and Development (R\&D) investment (K), in €k: cash investment by the companies. It excludes cooperative R\&D like venture R\&D investment with other companies or governments. Moreover, we computed it according to the accounting definitions of R\&D.

- Capital (C) €k, is the expenditure used by a company to acquire or upgrade physical assets; disclosed in accounts as additions to tangible fixed assets.

- Labor (L): the total number of employees.

Table 1. shows the summary of descriptive statistics.

Table 1. Sample descriptive statistics

\begin{tabular}{|l|l|l|l|l|r|}
\hline & count & mean & sd & min & max \\
\hline S & 467 & 2654.316 & 10561.2 & 0 & 175332.1 \\
\hline C & 467 & $1,6.6272$ & 350.9446 & 0 & 3210.817 \\
\hline K & 467 & 315.2003 & 1046.542 & 21.52293 & 9001.565 \\
\hline L & 467 & 6814.116 & 19877.57 & 0 & 222305 \\
\hline N & 467 & & & & \\
\hline
\end{tabular}




\section{Results}

Table 2 presents the outcome of OLS regression of Equation (3).

Table 2. Production function estimates

\begin{tabular}{|c|c|c|c|}
\hline & $\begin{array}{c}(1) \\
l \_\mathrm{SL}\end{array}$ & $\begin{array}{c}(2) \\
l \leq \mathrm{SL}\end{array}$ & $\begin{array}{c}(3) \\
l \_\mathrm{SL}\end{array}$ \\
\hline l_CL & $\begin{array}{c}0.0926 \\
(1.09)\end{array}$ & $\begin{array}{l}0.0538 \\
(0.58)\end{array}$ & $\begin{array}{l}0.123 \\
(1.01)\end{array}$ \\
\hline l_KL & $\begin{array}{c}0.0993 \\
(1.87)\end{array}$ & $\begin{array}{l}0.103 \\
(1.69)\end{array}$ & $\begin{array}{c}0.327 * * \\
(3.32)\end{array}$ \\
\hline$l \_\mathrm{L}$ & $\begin{array}{c}0.322 * * * \\
(8.08)\end{array}$ & $\begin{array}{c}0.366 * * * \\
(7.78)\end{array}$ & $\begin{array}{c}0.162 * * \\
(2.73)\end{array}$ \\
\hline _cons & $\begin{array}{c}-3.391 * * * \\
(-7.17)\end{array}$ & $\begin{array}{c}-3.841 * * * \\
(-7.20)\end{array}$ & $\begin{array}{l}-1.010 \\
(-1.29)\end{array}$ \\
\hline $\mathrm{N}$ & 339 & 259 & 80 \\
\hline
\end{tabular}

t statistics in parentheses

$* \mathrm{p}<0.05, * * \mathrm{p}<0.01, * * * \mathrm{p}<0.001$.

Dependent variable $-\log ($ Sales/Employees):

(1) Cross-sector; (2) Pharmaceuticals and biotechnology; (3) Health care equipment and services.

In the case of the complete sample (1), only the labor coefficient shows statistical significance and considerable magnitude. However, its value drops by half when one introduces industry controls. The R\&D capital only appears significant for health care equipment and services sector and triples in size compared to cross-sector and pharmaceuticals estimation. The R\&D elasticity outperforms the labor elasticity, but only when we control for industry specifics. This unusual result probably effects from omitted variable bias and the fact that the dependent variable (Sales) remains sensitive to industry characteristics like the phenomenon of vertical integration. Table 3 gathers the results of estimation of FDL model expressed in Equation 6.

Since we have two lags, the estimated equation is an FDL model of order 2. The estimates remain fairly unified across different samples and statistically significant. The model does not allow for evaluation of the impact multiplier $\left(\delta_{0}\right)$ due to the issue of collinearity but does allow for the evaluation of permanent effects of increasing R\&D investments. If an average company from our sample considers to permanently increase its R\&D investments by $1 \%$ annually, then the predicted ceteris paribus effect of this increase will emerge as a nearly $1.3 \%$ increase in sales (long-run multiplier $=\delta_{0}+\delta_{1}+\delta_{2}$ ). This value seems consistent with the characteristics of the health care industry, which has 
extended life-cycles in comparison to other sectors but cannot boast immediate effects of its R\&D endeavors.

Table 3. FDL model estimates

\begin{tabular}{|c|c|c|c|}
\hline & $\begin{array}{l}\text { (1) } \\
\text { l_S }\end{array}$ & $\begin{array}{l}\text { (2) } \\
\text { l_S }\end{array}$ & $\begin{array}{l}\text { (3) } \\
\text { l_S }\end{array}$ \\
\hline$l_{\text {l_delta__ }} \mathrm{K}$ & $\begin{array}{c}1.215^{* * *} \\
(9.89)\end{array}$ & $\begin{array}{c}1.311^{* * *} \\
(12.08)\end{array}$ & $\begin{array}{c}1.254^{* * *} \\
(13.26)\end{array}$ \\
\hline _cons & $\begin{array}{l}0.159 \\
(0.23)\end{array}$ & $\begin{array}{c}-2.208 * * * \\
(-3.51)\end{array}$ & $\begin{array}{c}-1.406 * * * \\
(-2.59)\end{array}$ \\
\hline $\mathrm{N}$ & 84 & 234 & 318 \\
\hline
\end{tabular}

t statistics in parentheses

$* \mathrm{p}<0.05,{ }^{* *} \mathrm{p}<0.01, * * * \mathrm{p}<0.001$.

Dependent variable: $\log ($ Sales):

(1) Health care equipment \& services; (2) Pharmaceuticals \& biotechnology; (3) Cross-sector.

\section{Discussion and conclusion}

The results of our study confirm the importance of R\&D investments as the key element of securing not only the development and financial stability of the health care industry but also reveals R\&D efforts as the principal drivers of better health outcomes. However, recent studies confirm the decrease of returns from R\&D investments in the health industry and the increasing volatility of sales and profits (Health Affairs, 2015). The reversal of these negative trends mostly depends on the implementation of policy responses that will seek reducing uncertainty and rewarding innovation. First, since medical innovation displays large public returns, there should be more financial support for health-related research coming from the public purse. From this particular standpoint, Europe is lagging behind the US R\&D spending levels (see Figure 1).

Therefore, especially Europe should hasten the creation of joint public-private research initiatives. Second, since the early stages of R\&D embedded in final medical products - drugs and equipment - are extremely risky in terms of the success of the entire value chain, public policy should focus on alleviating barriers in obtaining market access. For instance, there already are initiatives that seek accelerating drug approval processes through the awarding of breakthrough therapy designations for pharmaceuticals clinically effective in life-threatening conditions. Third, administrations should simplify patenting procedures. Patent protection for medical products is especially important compared to other industries, in which the manufacturing process usually requires 
a small fraction of resources used by pharma companies. Moreover, public authorities should more efficiently regulate intellectual property markets, thus reducing patent thickets. Finally, public authorities should provide all agents operating within the health care system - health industry companies, health care providers, and payers - with more incentives to cooperate. Only coordinated actions will enhance R\&D efforts, provide faster access to innovation, and raise health outcomes.

Figure 1. Private and public health-related R\&D (2004-2012; billion euro)

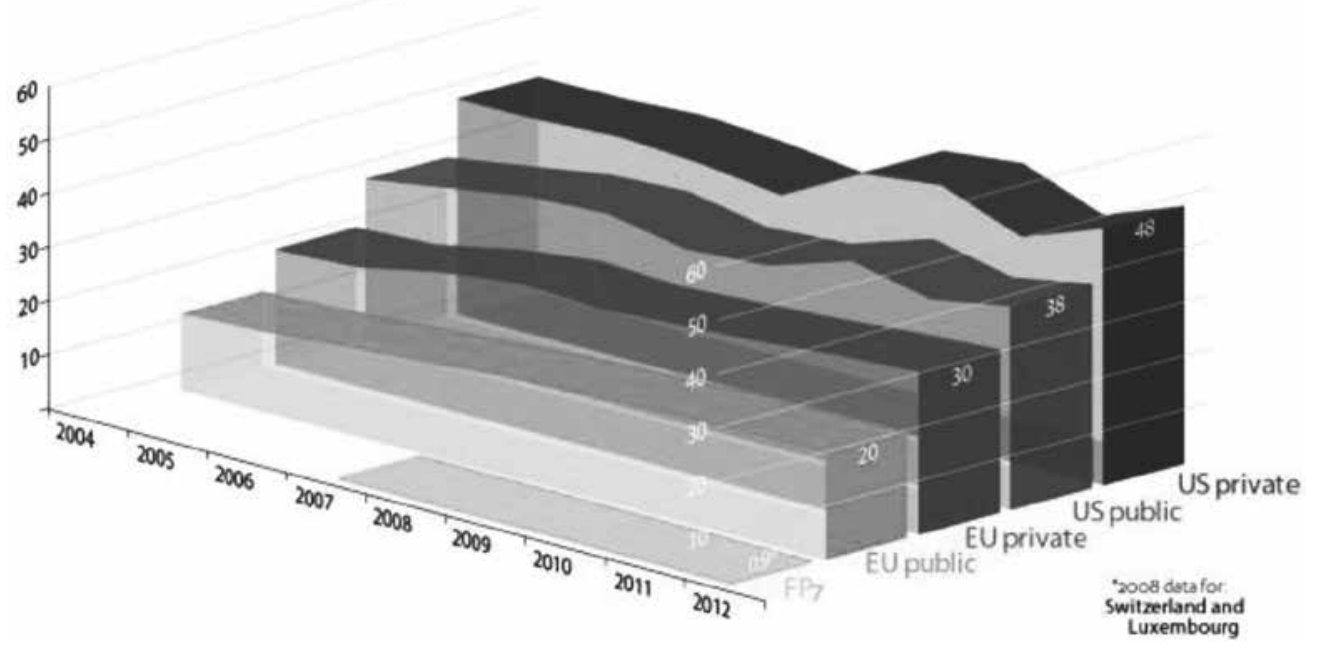

Source: adapted from Politico, available at http://www.politico.eu/sponsored-content/are-levels-of-health-rd-investment-in-europe-suffi-cient-to-cope-with-health-challenges/ (10.09.16).

\section{References}

Al-Horani, A., Pope, P.F. and Stark, A.W. (2003). Research and development activity and expected returns in the United Kingdom. European Finance Review, 7: 27-46, https://doi.org/10.1023/A:1022504029943

Arrow, K. (1962). Economic welfare and the allocation of resources for invention. In The rate and direction of inventive activity: Economic and social factors. Princeton: Princeton University Press, https://doi.org/10.1515/9781400879762-024

Artz, Kendall W. et al. (2005). A longitudinal study of the impact of R\&D, patents, and product innovation on firm performance, Journal of Product Innovation Management, 27(5): 725-740, https://doi.org/10.1111/j.1540-5885.2010.00747.x

Aw, B.Y., Roberts, M.J. and Yi Xu, D. (2011). R\&D investment, exporting, and productivity dynamics. The American Economic Review, 101(4): 1312-1344, https://doi.org/10.1257/aer.101.4.1312

Ballester, M., Garcia-Ayuso, M. and Livnat, J. (2003). The economic value of the R\&D intangible asset. European Accounting Review, 12(4): 605-633,

https://doi.org/10.1080/09638180310001628437 
Barth, M., Kasznik, R. and McNichols, M. (2001). Analyst coverage and intangible assets. Journal of Accounting Research, 39(1): 1-34, https://doi.org/10.1111/1475-679X.00001

Berndt, E.R., Nass, D., Kleinrock, M. and Aitken, M. (2015). Decline in economic returns from new drugs raises questions about sustaining innovations. Health Affairs, 34(2): 245-252, https://doi.org/10.1377/hlthaff.2014.1029

Bilbao-Osorio, Be-at and Rodríguez-Pose, A. (2004). From R\&D to innovation and economic growth in the EU. Growth and Change, 35(4): 434-455, https://doi.org/10.1111/j.1468-2257.2004.00256.x

Bloom, N., Schankerman, M. and Van Reenen, J. (2013). Identifying technology spillovers and product market rivalry. Econometrica, 81(4): 1347-1393, https://doi.org/10.3982/ECTA9466

Blundell, R., Griffith, R. and Van Reenen, J. (1999). Market share, market value and innovation in a panel of British manufacturing firms. The Review of Economic Studies, 66(3): 529-554, https://doi.org/10.1111/1467-937X.00097

Bogliacino, F. and Vivarelli, M. (2012). The job creation effect of R\&D expenditures, Australian Economic Papers, 51(2): 96-113.

Bosworth, D. and Rogers, M. (2001). Market value, R\&D and intellectual property: an empirical analysis of large Australian firms. Economic Record, 77(239): 323-337, https://doi.org/10.1111/1475-4932.t01-1-00026

Bowonder, B. et al. (2010). Innovation strategies for creating competitive advantage. Research-technology management, 53(3): 19-32, https://doi.org/10.1080/08956308.2010.11657628

Canibano, L., Garcia-Ayuso, M. and Sanchez, P. (2000). Accounting for intangibles: a literature review, Journal of Accounting Literature, 19: 102-130.

Chambers, D., Ross, J. and Thompson, R.B. (2002). Excess returns to R\&D-intensive firms, Review of Accounting Studies, 7(2): 133-158, https://doi.org/10.1023/A:1020217817156

Cockburn, I.M. and Griliches, Z. (1988). Industry effects and appropriability measures in the stock markets valuation of R\&D and patents. The American Economic Review, 78(2): 419-423.

Deloitte (2014). Measuring the return from pharmaceutical innovation 2014: Turning the corner?

Deloitte Centre for Health Solutions.

García-Manjón, J.V. and Romero-Merino, M.E. (2012). Research, development, and firm growth. Empirical evidence from European top R\&D spending firms. Research Policy, 41(6): 1084-1092.

Doraszelski, U. and Jaumandreu, J. (2013). R\&D and productivity: Estimating endogenous productivity. The Review of Economic Studies, 80(4): 1338-1383, https://doi.org/10.1093/restud/rdt011

Fleming, J.J. (2015). The decline of venture capital investment in early-stage life sciences poses a challenge to continued innovation. Health Affairs, 34(2): 271-276,

https://doi.org/10.1377/hlthaff.2014.1051

Griliches, Z. (1979). Issues in assessing the contribution of research and development to productivity growth. The Bell Journal of Economics, 10(1): 92-116, https://doi.org/10.2307/3003321

Griliches, Z. (1981). Market value, R\&D, and patents. Economics Letters, 7(2): 183-187, https://doi.org/10.1016/0165-1765(87)90114-5

Griliches, Z. (1986). Productivity, R\&D, and Basic Research at the Firm Level in the 1970's. American Economic Review, 76(1): 141-154.

Griliches, Z. (1998). Market value, R\&D, and patents. Economics letters, 7(2): 183-187, https://doi.org/10.1016/0165-1765(87)90114-5

Hall, B.H. (1993). The stock market's valuation of R\&D investment during the 1980's. The American Economic Review, 83(2): 259-264. 
Hall, B.H. and Oriani, R. (2006). Does the market value R\&D investment by European firms? Evidence from a panel of manufacturing firms in France, Germany, and Italy. International Journal of Industrial Organization, 24(5): 971-993, https://doi.org/10.1016/j.ijindorg.2005.12.001

Hall, H.B. and Mairesse, J. (2009). Measuring corporate R\&D returns. Presentation to the Knowledge for Growth Expert Group, Directorate General for Research, European Commission, Brussels, January.

Harhoff, D. (1998). R\&D and Productivity in German Manufacturing Firms. Economics of Innovation and New Technology, 6(1): 29-50, https://doi.org/10.1080/10438599800000012

Health Affairs (2015). Biomedical innovation, 34(2): 193-360.

Hitt, M.A. et al. (1991). Effects of acquisitions on R\&D inputs and outputs. Academy of Management Journal, 34(3): 693-706.

Hsieh, Ping-Hung, Mishra, Ch.S. and Gobeli, D.H. (2003). The return on R\&D versus capital expenditures in pharmaceutical and chemical industries. IEEE Transactions on Engineering Management, 50(2): 141-150, https://doi.org/10.1109/TEM.2003.810828

JRC (2015). The 2015 EU Industrial R\&D Investment Scoreboard. Publication Office of the European Union, Luxembourg. doi:10.2791/15792

Lai, Ming-Fong, and Gwo-Guang Lee (2007). Risk-avoiding cultures toward achievement of knowledge sharing. Business Process Management Journal, 13(4): 522-537, https://doi.org/10.1108/14637150710763559

Li, Dongmei (2011). Financial constraints, R\&D investment, and stock returns. Review of Financial Studies, 24(9): 2974-3007, https://doi.org/10.1093/rfs/hhr043

Lichtenberg, F.R. (1992). R\&D investment and international productivity differences, 4161, National Bureau of Economic Research, https://doi.org/10.3386/w4161

Lichtenberg, F.R. (2003). The economic and human impact of new drugs. The Journal of Clinical Psychiatry, 64(suppl 17): 15-18.

Lichtenberg, F.R. and Siegel, D. (1991). The impact of R\&D investment on productivity-New evidence using linked R\&D-LRD data. Economic Inquiry, 29(2): 203-229, https://doi.org/10.1111/j.1465-7295.1991.tb01267.x

Mairesse, J. and Sassenou, M. (1991). R\&D and Productivity: A Survey of Econometric Studies at the Firm Level. Science-Technology-Industry Review, 8: 317-348.

Mairesse, J. and Mohnen, P. (2005). The importance of R\&D for innovation: a reassessment using French survey data. Springer US, https://doi.org/10.1007/0-387-25022-0_10

Milbergs, E. and Vonortas, N. (2004). Innovation metrics: Measurement to insight. Center for Accelerating Innovation and George Washington University, National Innovation, Initiative 21st Century Working Group 22.

Morbey, G.K. and Reithner, R.M. (1990). How R\&D affects sales growth, productivity and profitability. Research-Technology Management, 33(3): 11-14, https://doi.org/10.1080/08956308.1990.11670656

Nagaoka, S. (2006). R\&D and market value of Japanese firms in the 1990s. Journal of the Japanese and International Economies, 20(2): 155-176, https://doi.org/10.1016/j.jjie.2005.07.001

Nissim, D. and Thomas, J. (2000). R\&D costs and accounting profits. University of Haifa, Zimmerman Foundation Discussion Paper ZF-01-01.

Paul, S.M., Mytelka, D.S., Dunwiddie, C.T., Persinger, C.C., Munos, B.H., Lindborg, S.R. and Schacht, A.L. (2010). How to improve R\&D productivity: the pharmaceutical industry's grand challenge. Nature Reviews Drug discovery, 9(3): 203-214, https://doi.org/10.1038/nrd3078 
Sougiannis, T. (1994). The Accounting Based Valuation of Corporate R\&D. The Accounting Review, 69(1): 44-68.

Thomson-Reuters (2016). Disruptive, game-changing innovation. 2016 State of Innovation. Reuters.

Toivanen, O., Stoneman, P. and Bosworth, D. (2002). Innovation and the market value of UK firms, 1989-1995. Oxford Bulletin of Economics and Statistics, 64(1): 39-61, https://doi.org/10.1111/1468-0084.00002

Tubbs, M. (2007). The relationship between R\&D and company performance. Research-Technology Management, 50(6): 23-30, https://doi.org/10.1080/08956308.2007.11657470

Wang, J. and Chung-Yu Yang (2012). Flexibility planning for managing R\&D projects under risk. International Journal of Production Economics, 135(2): 823-831, https://doi.org/10.1016/j.ijpe.2011.10.020

Yunkui, Xue and Wang Zhitai (2001). The Importance of R\&D and the Improvement of Its Disclosure. Accounting Research, 3. 